\title{
Effect of Gender and Physical Activity Level on Sit-to-Stand Test Performance Among Young Adults
}

\section{Genç Yetişkinlerde Cinsiyet ve Fiziksel Aktivite Seviyesinin Otur-kalk Test Performansı Üzerine Etkisi}

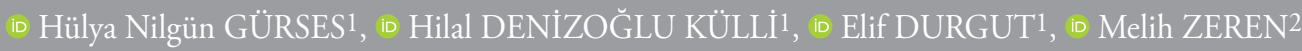

1Bezmialem Vakif University Faculty of Health Sciences, Division of Physiotherapy and Rehabilitation, İstanbul, Turkey

2̇̇zmir Bakırçay University Faculty of Health Sciences, Division of Physiotherapy and Rehabilitation, İzmir, Turkey

\section{ABSTRACT}

Objective: Our study aimed to determine the sit-to-stand (STS) test performance and physical activity levels of young adults and investigate the relationship of STS tests with gender and physical activity levels.

Methods: Sixty volunteers randomly performed the $5 \times$ STS, 10sSTS, 30sSTS and 60sSTS tests. Fatigue was rated using the Borg category ratio scale. Physical activity level and weekly energy expenditure of volunteers were calculated using the International Physical Activity Questionnaire.

Results: The 5xSTS, 10sSTS, 30sSTS and 60sSTS test scores were statistically different between genders ( $\mathrm{p}=0.004 ; \mathrm{p}=0.002$; $\mathrm{p}=0.000 ; \mathrm{p}=0.000$, respectively). Fatigue levels after STS tests did not show any difference between genders $(p=0.636 ; p=0.295$; $\mathrm{p}=0.888 ; \mathrm{p}=0.150$, respectively). Weekly energy expenditures were positively correlated with STS tests except $5 \times$ STS test $(r=-0.458$, $\mathrm{p}=0.000 ; \mathrm{r}=0.427, \mathrm{p}=0.001 ; \mathrm{r}=0.606, \mathrm{p}=0.000 ; \mathrm{r}=0.545, \mathrm{p}=0.000$, respectively). All STS tests had significant differences between participants with moderate or high physical activity level $(\mathrm{p}=0.016$; $\mathrm{p}=0.007 ; \mathrm{p}=0.000 ; \mathrm{p}=0.000$, respectively).

Conclusion: Our study shows that STS tests scores correlate to gender and physical activity levels in young adults.

Keywords: Sit-to stand test, functional capacity, weekly energy expenditure, adolescent

\section{ÖZ}

Amaç: Genç yetişkinlerde otur-kalk test (OKT) performansını ve fiziksel aktivite seviyesini belirleyerek OKT performansının cinsiyetle ve fiziksel aktivite seviyesi ile ilişkisini belirlemektir.

Yöntemler: Altmış gönüllü rastgele sırayla 5 tekrarlı OKT, 10 sn OKT, 30 sn OKT ve 60 sn OKT'lerini gerçekleştirdi. Test sonu yorgunluk seviyeleri Borg Yorgunluk skalasıyla değerlendirildi. Katılımcıların fiziksel aktivite seviyeleri ve haftalık enerji tüketimi değerleri Uluslararası Fiziksel Aktivite Anketi kullanılarak belirlendi.

Bulgular: Kadın ve erkek katılımcılar arasında 5 tekrarlı OKT, 10 sn OKT, 30 sn OKT ve 60 sn OKT skorlarında istatistiksel olarak anlamlı farklılık tespit edildi (sırasıyla, $\mathrm{p}=0,004 ; \mathrm{p}=0,002 ; \mathrm{p}=0,000$; $\mathrm{p}=0,000)$. OKT sonundaki yorgunluk seviyelerinde ise anlamlı bir fark bulunmadı (sırasıla, $\mathrm{p}=0,636 ; \mathrm{p}=0,295 ; \mathrm{p}=0,888 ; \mathrm{p}=0,150$ ). Tüm katılımcıların haftalık enerji tüketimi değerleri 5 tekrarlı OKT skoru dışında tüm testlerle pozitif olarak ilişkili bulundu (sirasiyla, $r=-0,458, p=0,000 ; r=0,427, p=0,001 ; r=0,606, p=0,000$; $\mathrm{r}=0,545, \mathrm{p}=0,000)$. Orta ve yüksek fiziksel aktivite seviyesine sahip katılımcıların OKT skorları karşılaştırıldığında istatistiksel olarak anlamlı farklar saptandı (sırasıyla, $p=0,016 ; p=0,007 ; p=0,000$; $\mathrm{p}=0,000)$.

Sonuç: Bizim çalışmamız genç yetişkinlerde OKT performansının cinsiyetle ve fiziksel aktivite seviye ile ilişkili olduğunu göstermektedir.

Anahtar Sözcükler: Otur-kalk testi, fonksiyonel kapasite, haftalık enerji tüketimi, adölesan
Address for Correspondence: Hülya Nilgün GÜRSES, Bezmialem Vakıf University Faculty of Health Sciences, Division of Physiotherapy and Rehabilitation, i̇stanbul, Turkey

E-mail: ngurses@bezmialem.edu.tr ORCID ID: orcid.org/0000-0002-5846-6781
Received: 22.07.2019

Accepted: 29.09.2019

Cite this article as: Gürses HN, Denizoğlu Külli H, Durgut E, Zeren M. Effect of Gender and Physical Activity Level on Sit-to-Stand Test Performance Among Young Adults. Bezmialem Science 2020;8(3):222-6. 


\section{Introduction}

The sit-to-stand (STS) manoeuvre is one of the essential activities for mobility according to the International Classification of Functioning, Disability, and Health (1). It is generally used as a measure of knee extensor strength (2). STS tests that include more than a single repetition of STS manoeuvre assess physical fitness and functional capacity in elderly people (3). Several variations of STS test exist; five repetitions $(5 \times$ STS $), 10 \mathrm{~s}, 30$ $s$ and $60 \mathrm{~s}$ STS (10sSTS, 30sSTS and 60sSTS) tests are the most frequently used tests in studies and clinical practice (4-7). These are generally used among the older population and some neurological conditions $(8,9)$.

Physical activity is defined as any bodily activities produced by the skeletal muscles and joints that result in energy expenditure, heart rate and respiratory frequency increment and fatigue in different levels (10). Physical activity level is generally classified as high, moderate and low. Functional capacity is known to be associated with physical activity level of healthy men and women (11). In addition, sex-related differences in physical activity show that male adolescents are more physically active than female adolescents $(12,13)$. However, studies comparing STS test performance among different physical activity levels and between genders in the young population are limited $(8,9,14)$. This leads to difficulties in comparing the STS performance of young patients to their age and gender-matched healthy controls.

This study aimed to determine STS test performance and physical activity levels of young adults and investigate the relationship of STS tests with gender and physical activity levels.

\section{Method}

\section{Study Design}

Sixty healthy volunteers ( 30 women and 30 men) aged between 18 and 25 years were included in the study. Exclusion criteria were participation in competitive sports, smoking, hospitalisation history in the last 6 months, diagnosed chronic diseases which may affect exercise capacity, diagnosed visual and/or vestibular disorders and pathologies, and pain in the lower extremities that may impede mobilisation (traumas, fractures, etc.).

The demographic data of subjects were recorded. All participants performed the STS tests $(5 \times$ STS, 10sSTS, 30sSTS and 60sSTS tests), and physical activity levels of participants were assessed using the International Physical Activity Questionnaire-Short Form (IPAQ-SF) on the same day.

The aim of the study and testing methods were explained to the participants in advance, and informed consent was obtained before testing. The research was approved by the research ethics committee of the university hospital (protocol number: 71306642/050-01-04/07).

\section{Outcome Measures}

\section{Sit-to-Stand Tests}

STS tests were performed according to Bohannon's 2012 guideline (15). A standard height chair $(45 \mathrm{~cm})$ without arm rests which was stabilised against the wall, was used for testing. The participants were instructed to move forward until their feet are flat on the floor. They were instructed to stand up all the way and sit down as fast as possible while the upper limbs were folded across the chest for five times and also for 10, 30 and 60 s. The order of the tests was determined by random draw. The time required for completing five STS manoeuvres was measured for $5 \times$ STS test, and the number of completed STS manoeuvres in the given period was recorded for the timed tests. 5-min rest intervals were given between each STS test. Fatigue was rated using the modified Borg scale after each test.

\section{Physical Activity}

The IPAQ-SF includes seven questions divided into frequency, intensity and duration of participation in physical activities at low (walking), moderate and vigorous levels, and quantifies the total physical activity for the past week. The data collected are reported as continuous data (expressed as metabolic equivalent task [MET-min/week]) and as a categorical score (divided into low [<600 MET-min/week], moderate [600-3000 MET-min/ week] and high [>3000 MET-min/week] activity level) (16).

\section{Statistical Analysis}

Statistical analysis was performed using SPSS software (Version 16.0; SPSS; Chicago, IL, USA). Normality of all variables was tested using the Shapiro-Wilk test. The differences in functional capacity, fatigue level after STS tests between female and male subjects and difference in STS scores between subjects with moderate and high physical activity levels were analysed using the chi-squared test and Student t-test. The correlation between weekly energy expenditure and STS test scores were analysed using Pearson correlation coefficient $(r=$ at least 0.8 , very strong; $0.6-0.8$, moderately strong; $0.3-0.5$, good; and $<0.3$, poor). The significance level for tests was determined as 95\% ( $<<0.05)$.

The sample size of the study was determined using G-Power 3.1 software (Universität Dusseldorf, Germany) (17). Literature suggests that the effect size of the difference between functional capacity of men and women is 0.88 (18). Considering this, minimum of 22 subjects were needed for each gender to detect this difference with 95\% confidence level and $80 \%$ power.

\section{Results}

Demographic data (age, sex, height, weight and body mass index [BMI]), weekly energy expenditure and physical activity levels of participants are shown in Table 1 . Of the female participants, $22(73 \%)$ and $8(27 \%)$ had moderate and high physical activity levels, respectively; of the male participants, 14 (47\%) and 16 (53\%) had moderate and high physical activity levels, respectively (between gender difference, $\mathrm{p}=0.025$ ). None of the participants had low physical activity level.

Statistically significant differences were found in all STS tests between women and men $(5 \times$ STS, $\mathrm{p}=0.004 ; 10 \mathrm{sSTS}, \mathrm{p}=0.002$; 30sSTS, $\mathrm{p}=0.000$; 60sSTS, $\mathrm{p}=0.000$ ) (Table 2). 
Fatigue levels after $\mathrm{STS}$ tests did not show any difference between genders $(5 \times$ STS, $p=0.636 ; 10 s S T S, p=0.295$; 30sSTS, $p=0.888$; 60sSTS, $\mathrm{p}=0.150$ ) (Table 3).

Weekly energy expenditures were correlated to STS tests $(5 \times$ STS, $\mathrm{r}=-0.458, \quad \mathrm{p}=0.000 ; \quad 10 \mathrm{~s} T \mathrm{~S}, \quad \mathrm{r}=0.427, \quad \mathrm{p}=0.001 ; 30 \mathrm{sSTS}$, $\mathrm{r}=0.606, \mathrm{p}=0.000$; 60sSTS, $\mathrm{r}=0.545, \mathrm{p}=0.000)$ (Table 4).

Table 1. Demographic data and MET, level of physical activity

\begin{tabular}{|c|c|c|c|c|}
\hline & & $\begin{array}{l}\text { Female } \\
(n=30) \\
X \pm S D\end{array}$ & $\begin{array}{l}\text { Male } \\
(n=30) \\
X \pm S D\end{array}$ & $\mathrm{p}$ \\
\hline \multicolumn{2}{|c|}{ Age (year) } & $22.13 \pm 1.16$ & $22.33 \pm 1.26$ & 0.111 \\
\hline \multicolumn{2}{|c|}{ Height (m) } & $1.61 \pm 0.06$ & $1.76 \pm 0.04$ & 0.000 * \\
\hline \multicolumn{2}{|c|}{ Weight (kg) } & $57.27 \pm 7.73$ & $73.83 \pm 9.70$ & $0.000 *$ \\
\hline \multicolumn{2}{|c|}{ BMI $\left(\mathbf{k g} \cdot \mathbf{m}^{-2}\right)$} & $21.97 \pm 2.34$ & $22.97 \pm 2.59$ & 0.064 \\
\hline \multicolumn{2}{|c|}{ MET.min.wk ${ }^{-1}$} & $1909 \pm 1148$ & $3503 \pm 2250$ & 0.001 * \\
\hline \multirow{2}{*}{$\begin{array}{l}\text { Physical } \\
\text { activity } \\
\text { level }\end{array}$} & Moderate & $22(73 \%)$ & $14(47 \%)$ & \multirow[b]{2}{*}{$0.025^{* *}$} \\
\hline & High & $8(27)$ & $16(53 \%)$ & \\
\hline
\end{tabular}

All STS tests had significant differences between participants with moderate or high physical activity level $(5 \times S T S, p=0.016$; 10sSTS, $\mathrm{p}=0.007$; 30sSTS, $\mathrm{p}=0.000$; 60sSTS, $\mathrm{p}=0.000$ ) (Table 5).

\section{Discussion}

The present study showed that gender-related differences are present for all STS tests. In addition, STS tests had a moderate correlation with weekly energy expenditure and were affected by the physical activity level of the participants.

Table 2. Effects of gender on functional capacity measured by STS tests

\begin{tabular}{l|l|l|l|} 
& $\begin{array}{l}\text { Female } \\
(\mathrm{n}=30) \\
\mathrm{X} \pm \mathrm{SD}\end{array}$ & $\begin{array}{l}\text { Male } \\
(\mathrm{n}=30) \\
\mathrm{X} \pm \mathrm{SD}\end{array}$ & $\mathrm{p}$ \\
\hline $\begin{array}{l}\mathbf{5} \text { × STS test (s) } \\
\text { 10sSTS test (number of } \\
\text { repetitions) }\end{array}$ & $6.07 \pm 1.13$ & $5.15 \pm 1.26$ & $0.004 *$ \\
\hline $\begin{array}{l}\text { 30sSTS test (number of } \\
\text { repetitions) }\end{array}$ & $21.67 \pm 2.74$ & $25.67 \pm 4.77$ & 0.000 * \\
\hline $\begin{array}{l}\text { 60sSTS test (number of } \\
\text { repetitions) }\end{array}$ & $41.10 \pm 6.33$ & $49.40 \pm 10.5$ & 0.000 * \\
\hline *p<0.05, SD: Standard deviation, STS: Sit-to-stand & & \\
\hline
\end{tabular}

Table 3. Effects of gender on fatigue level after STS tests

\begin{tabular}{|c|c|c|c|c|}
\hline & & $\begin{array}{l}\text { Female } \\
(n=30) \\
X \pm S D\end{array}$ & $\begin{array}{l}\text { Male } \\
(n=30) \\
X \pm S D\end{array}$ & $\mathrm{p}$ \\
\hline \multirow{3}{*}{ Modified Borg Scale (0-10) } & After $5 \times$ STS test & $0.37 \pm 0.65$ & $0.45 \pm 0.69$ & 0.636 \\
\hline & After 30 sSTS test & $1.98 \pm 1.47$ & $2.03 \pm 1.26$ & 0.888 \\
\hline & After 60 sSTS test & $4.13 \pm 2.16$ & $4.90 \pm 1.90$ & 0.150 \\
\hline
\end{tabular}

SD: Standard deviation, STS: Sit-to-stand

Table 4. Correlation of weekly energy expenditure to sit-to-stand tests $(n=60)$

\begin{tabular}{|c|c|c|c|c|c|}
\hline & & $5 \times$ STS test & 10sSTS test & 30sSTS test & 60 sSTS test \\
\hline $\begin{array}{l}\text { Weekly energy expenditure } \\
\text { (MET min } w^{-1} \text { ) }\end{array}$ & $r$ & $\begin{array}{l}-0.458 \\
0.000 *\end{array}$ & $\begin{array}{l}0.427 \\
0.001 *\end{array}$ & $\begin{array}{l}0.606 \\
0.000 *\end{array}$ & $\begin{array}{l}0.545 \\
0.000 *\end{array}$ \\
\hline
\end{tabular}

${ }^{*} \mathrm{p}<0.05$, STS: Sit-to-stand, MET: Metabolic equivalent task, min: Minimum

Table 5. Effects of physical activity level on functional capacity measured by STS tests

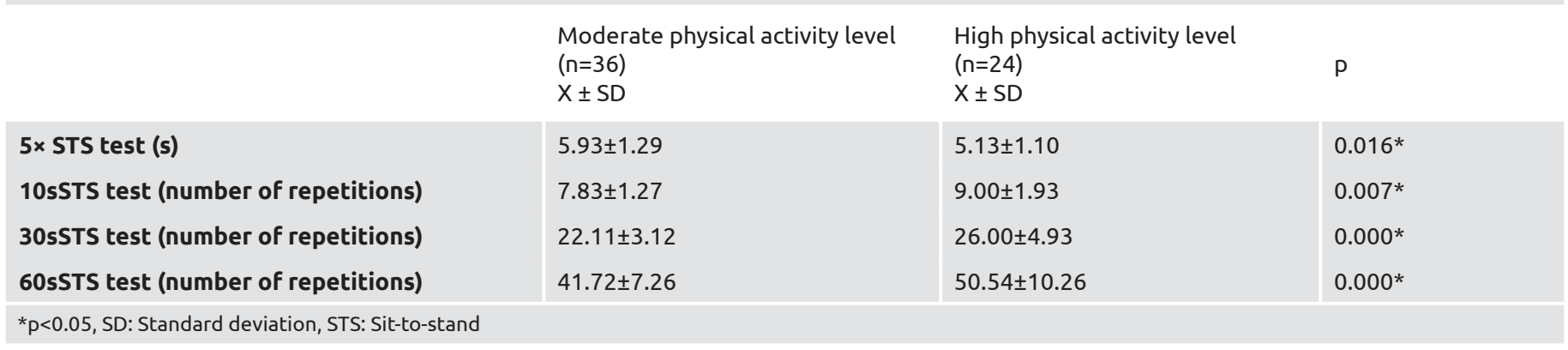


Most of the previous studies showed that men are more physically active than women (19-22). However, there is no consensus about it. Vašičcková et al. compared the physical activity levels between genders using the IPAQ and pedometer. The study did not show any differences in the average daily steps but reported that fewer women participated in vigorous and moderate physical activity according to IPAQ (23). Our study presented that almost half of the male subjects had high physical activity level (53\%), whereas only $27 \%$ of females were at the same level.

STS tests are simple and cheap clinical tests that require only a small space, a stopwatch and a chair. However, these tests are generally used in the literature to assess older adults, and only few studies investigated young adults $(8,14,24)$. Studies reported that men had greater scores than women for $5 \times$ STS and 60sSTS tests across a wide age span $(8,9,25)$. Bohannon et al. found that the mean $5 \times$ STS score was $6 \mathrm{~s}$ in the young population (age between 20 and 29 years) (9). Butler et al. reported that the median $5 \times$ STS test scores of men and women aged between 20 and 24 years were 50 and 47 repetitions, respectively, in the Swiss population (8). Tveter et al. found that 30 sSTS scores were different between men and women aged 18-29 years (27 and 26 repetitions, respectively) (26). In the present study, all STS test scores in men were higher than those in women. However, our STS test results were lower than those of previous studies. We speculated that different physical activity habits of different populations may affect STS scores. In addition, most female subjects in the present study had moderate physical activity level. To the best of our knowledge, no study investigated the effect of gender on 10sSTS test in young adults.

Previous studies indicate that the rating of perceived exertion (RPE) is not influenced by gender (27-29). The study of Faulkner $\mathrm{J}$ et al. suggests that the Borg scale reflects exercise intensity independent from gender, age, exercise modality or physical activity level in healthy young adults (28). In our study, RPE was assessed using the Borg scale. The findings showed that Borg scores after STS tests were not different between women and men, which supported the results of the previous studies (25-27). The study of Scherr J et al. indicates that Borg scale reflects exercise intensity independent of gender, age, exercise modality or physical activity level in healthy young adults, as well (30).

Weekly energy expenditure can be calculated from self-reported questionnaires. A study showed that self-reported weekly energy expenditure, which was calculated using the Paffenbarger physical activity and exercise index, was related with $5 \times$ STS test score in patients with asthma (age range, between 21 and 77 years) (31). The $5 \times$ STS, 10sSTS, 30sSTS and 60sSTS tests have significant correlations with self-reported weekly energy expenditure in the present study. It suggests that self-reported weekly energy expenditure may provide information regarding functional capacity in healthy young adults. This idea is supported by another result of our study that STS scores were not the same between adults with moderate and high physical activity levels.

\section{Study Limitations}

As a limitation, the effect of gender on STS test scores in different physical activity levels was not analysed because of the small number of sample size of female subjects having high physical activity level.

\section{Conclusion}

In conclusion, our study shows that STS tests scores are different between young men and women. In addition, all STS tests can discriminate between subjects with moderate and high physical activity levels, indicating an interaction between STS performance and physical activity level. Future studies implementing STS tests in various diseases in young adults may benefit from our results for comparing the STS results of patients to healthy subjects.

\section{Ethics}

Ethics Committee Approval: The research was approved by the research ethics committee of the university hospital (protocol number: 71306642/050-01-04/07).

Informed Consent: Informed consent was obtained before testing.

Peer-review: Externally peer reviewed.

\section{Authorship Contributions}

Concept: H.N.G., Design: H.N.G., H.D.K., E.D., M.Z., Data Collection or Processing: H.N.G., H.D.K., E.D., M.Z., Analysis or Interpretation: H.N.G., H.D.K., E.D., M.Z., Literature Search: H.N.G., H.D.K., E.D., M.Z., Writing: H.N.G., H.D.K., E.D., M.Z.

Conflict of Interest: No conflict of interest was declared by the authors.

Financial Disclosure: The authors declared that this study received no financial support.

\section{References}

1. Organization WH. International classification of functioning, disability and health: ICF: World Health Organization; 2001.

2. Corrigan D, Bohannon RW. Relationship between knee extension force and stand-up performance in community-dwelling elderly women. Arch Phys Med Rehabil 2001;82:1666-72.

3. Bohannon RW. Reference values for the five-repetition sit-to-stand test: a descriptive meta-analysis of data from elders. Percept Mot Skills 2006;103:215-22.

4. Bohannon RW, Smith J, Hull D, Palmeri D, Barnhard R. Deficits in lower extremity muscle and gait performance among renal transplant candidates. Arch Phys Med Rehabil 1995;76:547-51.

5. Sterky E, Stegmayr B. Elderly patients on haemodialysis have $50 \%$ less functional capacity than gender-and age-matched healthy subjects. Scand J Urol Nephrol 2005;39:423-30.

6. Bohannon RW. Alternatives for measuring knee extension strength of the elderly at home. Clin Rehabil 1998;12:434-40. 
7. Reychler G, Audag N, Mestre NM, Caty G. Assessment of Validity and Reliability of the 1-Minute Sit-to-Stand Test to Measure the Heart Rate Response to Exercise in Healthy Children. JAMA Pediatr 2019;173:692-3.

8. Butler AA, Menant JC, Tiedemann AC, Lord SR. Age and gender differences in seven tests of functional mobility. J Neuroeng Rehabil 2009;6:31.

9. Bohannon RW, Bubela DJ, Magasi SR, Wang YC, Gershon RC. Sitto-stand test: performance and determinants across the age-span. Isokinet Exerc Sci 2010;18:235-40.

10. Bouchard C, Blair SN, Haskell WL. Physical activity and health: Human Kinetics; 2018.

11. Cheng YJ, Macera CA, Addy CL, Sy FS, Wieland D, Blair SN. Effects of physical activity on exercise tests and respiratory function. Br J Sports Med 2003;37:521-8.

12. Gavarry O, Giacomoni M, Bernard T, Seymat M, Falgairette G. Habitual physical activity in children and adolescents during school and free days. Med Sci Sports Exerc 2003;35:525-31.

13. Norman GJ, Nutter SK, Ryan S, Sallis JF, Calfas KJ, Patrick K. Community Design and Access to Recreational Facilities as Correlates of Adolescent Physical Activity and Body-Mass Index. J Phys Act Health 2006;3:118-28.

14. Gurses HN, Zeren M, Denizoglu Kulli H, Durgut E. The relationship of sit-to-stand tests with 6-minute walk test in healthy young adults. Medicine (Baltimore) 2018;97:e9489.

15. Bohannon RW. Measurement of Sit-to-Stand Among Older Adults. Topics in Geriatric Rehabilitation 2012;28:11-6.

16. Craig CL, Marshall AL, Sjöström M, Bauman AE, Booth ML, Ainsworth BE, et al. International physical activity questionnaire: 12-country reliability and validity. Med Sci Sports Exerc 2003;35:1381-95.

17. Faul F, Erdfelder E, Lang AG, Buchner A. G*Power 3: a flexible statistical power analysis program for the social, behavioral, and biomedical sciences. Behav Res Methods 2007;39:175-91.

18. Chetta A, Zanini A, Pisi G, Aiello M, Tzani P, Neri M, et al. Reference values for the 6-min walk test in healthy subjects 20-50 years old. Respir Med 2006;100:1573-8.

19. Monteiro CA, Conde WL, Matsudo SM, Matsudo VR, Bonsenor IM, Lotufo PA. A descriptive epidemiology of leisure-time physical activity in Brazil, 1996-1997. Rev Panam Salud Pública 2003;14:24654.
20. Burton NW, Turrell G. Occupation, hours worked, and leisure-time physical activity. Prev Med 2000;31:673-81.

21. Martinez-Gonzalez MA, Varo JJ, Santos JL, De Irala J, Gibney M, Kearney J, et al. Prevalence of physical activity during leisure time in the European Union. Med Sci Sports Exerc 2001;33:1142-6.

22. Steptoe A, Wardle J, Cui W, Bellisle F, Zotti AM, Baranyai R, et al. Trends in smoking, diet, physical exercise, and attitudes toward health in European university students from 13 countries, 1990-2000. Prev Med 2002;35:97-104.

23. Vasickova J, Groffik D, Frömel K, Chmielik F, Wasowicz W. Determining gender differences in adolescent physical activity levels using IPAQ long form and pedometers. Ann Agric Environ Med 2013;20:749-55.

24. Bohannon RW, Crouch R. 1-Minute Sit-to-Stand Test: Systematic Review of Procedures, Performance, And Clinimetric Properties. J Cardiopulm Rehabil Prev 2019;39:2-8.

25. Strassmann A, Steurer-Stey C, Lana KD, Zoller M, Turk AJ, Suter $\mathrm{P}$, et al. Population-based reference values for the 1-min sit-to-stand test. Int J Public Health 2013;58:949-53.

26. Tveter AT, Dagfinrud H, Moseng T, Holm I. Health-related physical fitness measures: reference values and reference equations for use in clinical practice. Arch Phys Med Rehabil 2014;95:1366-73.

27. Demello JJ, Cureton KJ, Boineau RE, Singh MM. Ratings of perceived exertion at the lactate threshold in trained and untrained men and women. Med Sci Sports Exerc 1987;19:354-62.

28. Faulkner J, Parfitt G, Eston R. Prediction of maximal oxygen uptake from the ratings of perceived exertion and heart rate during a perceptually-regulated sub-maximal exercise test in active and sedentary participants. Eur J Appl Physiol 2007;101:397-407.

29. Pincivero D, Polen R, Byrd B. Gender and contraction mode on perceived exertion. Int J Sports Med 2010;31:359-63.

30. Scherr J, Wolfarth B, Christle JW, Pressler A, Wagenpfeil S, Halle M. Associations between Borg's rating of perceived exertion and physiological measures of exercise intensity. Eur J Appl Physiol 2013;113:147-55.

31. Mancuso CA, Choi TN, Westermann H, Briggs WM, Wenderoth S, Charlson ME. Measuring physical activity in asthma patients: twominute walk test, repeated chair rise test, and self-reported energy expenditure. J Asthma 2007;44:333-40. 